\title{
バンコクにおける傾斜面日射量と分光放射照度推定手法の研究 METHODS TO ESTIMATE TILTED SURFACES GLOBAL AND SPECTRAL IRRADIANCE IN BANGKOK
}

\author{
田中昭雄*, 酒井孝司 ${ }^{* *}$, 石原 修*** \\ Akio TANAKA, Koji SAKAI and Osamu ISHIHARA
}

\begin{abstract}
Since 2006, we have been measuring irradiation, spectral irradiance, and other meteorological data for Bangkok, Thailand. This report describes two research results were obtained through research using those meteorological data. The first study was intended to find a method for presuming the amount of global solar radiation of the slope, tilted south by $14^{\circ}$, that can be expected to yield the maximum global irradiance in metropolitan Bangkok. First, we examined six previously reported models to separate horizontal global irradiance into direct and diffusion elements. Four other models were examined to estimate irradiance on tilted surfaces by direct and diffusion elements. The surface was tilted at a $14^{\circ}$ angle to the south. The prediction accuracy of the combination of two models was evaluated using the root mean square error (RMSE) values. Results showed the most appropriate combination of those models: a combination of $\mathrm{U}, \mathrm{W}$, and $\mathrm{Z}$ models with the isotropic sky irradiance model yielded the smallest RMSE value. The second investigation developed a method to estimate spectral irradiance using global irradiation values. Theoretically, distribution of the solar spectrum irradiance is determined by various factors such as airmass, atmospheric pressure, water vapor, solar altitude, turbidity of atmosphere, and the earth's albedo. For variables in this study, we used amounts of the horizontal global irradiation, airmass, rainfall, and precipitable water processed with the sigmoid function. We developed a method for estimating the amount of global irradiance on the tilted surface under optimum condition, and developed a precise estimation method for spectrum irradiance on a horizontal plane for metropolitan Bangkok.
\end{abstract}

Keywords : Spectral Irradiance, Tilted surface irradiance, Horizontal global irradiance, Diffuse irradiation 分光放射照度，傾斜面日射，全天日射，天空日射

\section{1.はじめに}

東南アジアでは，近年の急激な経済成長により，エネルギー消費が 急激に増大している ${ }^{1)}$ が, 化石エネルギーの高騰・地球温暖化問題な どから省エネルギーや新エネルギー導入が緊急課題となっている。と くに同地域は低緯度帯に位置しており, 太陽光資源が豊富なことから 太陽光エネルギーへの期待が大きい。この中で太陽光発電の効率的な 導入には，各地の傾斜面日射量を正確に把握するとともに，地域の分 光特性を考慮した最適な太陽電池の開発・導入が重要である。しかし 低緯度地域では日射量の計測箇所は少なく, 分光放射照度の計測箇所 も少ない。

傾斜面日射量は, 水平面全天日射量の計測から推定も可能であるが, その場合，全天日射量を直達成分と天空成分に分離し，その後傾斜面 の直達成分と天空成分を合成するという2 段階作業が必要となる。こ の分離，合成する計算法はそれぞれ日射直散分離法（以下"分離モデ ル"），日射合成法（以下"合成モデル"）と呼ばれている。曽我他 ${ }^{2)}$ は，既往の分離モデルと合成モデルの組み合わせを検討し，国内での 全天日射量から傾斜面日射量を推定する最適なモデルの組み合わせ
を明らかにした。分光放射照度は, 全天日射強度との相関性が高い ことから, 全天日射強度とその他気象データから, 推定する方法が 検討されており 3),4),5)，高い予測精度のモデルも提案されている。 しかしこれらの研究は, 全て中緯度帯を対象とした研究であり, 低 緯度帯での研究例は少ない。

（財）産業創造研究所は平成 17 年度に（独）新エネルギー・産業 総合開発機構から助成金を受け, タイ王国科学技術省国家科学技術開 発庁（NSTDA）と共同で, バンコク市郊外において, 日本製とタイ 国製の太陽電池 I-V カーブと裏面温度及び，屋外気象観測事業 ${ }^{1)}$ を行 った。計測開始は 2005 年 12 月であり, 現在も継続計測中である。

本研究では, この事業の計測データを用いて, バンコクを例に, 低 緯度帯の傾斜面日射量推定に最適な既存の分離モデルと既存の合成 モデルの組み合わせを検討するとともに，全天日射強度から分光放射 照度を推定するモデルを提案するものである。なお, 本研究では, 瞬 間的な日射の強さを日射強度, 単位時間 $\mathrm{u}$ における日射強度の積分 值を日射量と記して区別する。

\footnotetext{
* 熊本大学大学院自然科学研究科 特任教授 $\cdot$ 博士 (工学)

** 明治大学理工学部 准教授 $\cdot$ 博士 (工学)

*** 熊本大学大学院自然科学研究科 教授 $\cdot$ 工博

Special Appointed Prof., Graduate School of Science and Technology, Kumamoto University, Dr. Eng.

Assoc. Prof., Meiji University, Dr. Eng.

Prof., Graduate School of Science and Technology, Kumamoto University, Dr. Eng.
} 


\section{2. 研究手法}

\section{1 日射量など気象情報の計測}

気象計測箇所は，北緯 $14^{\circ}$ 東経 $100.5^{\circ}$ のタイ国 NSTDA 研究所敷 地内にある。図 1 に日射計の設置状況を示す。同助成事業は平成 18 年度末をもって終了したが，データ計測収集はNSTDA により現在も 継続中である。

計測システムは, 2 台の全天日射計, 2 種類の分光放射計, 外気温, 湿度, 風速, 風向, 30 枚の太陽電池モジュール (それぞれ I-V カーブ, 裏面温度測定）からなり，50ch データロガー2 台に接続されている。 表 1 はそこに設置されている日射計の仕様である。全天日射計は，英 弘精機株式会社製MS-802 で, 水平面と傾斜面（南向き, 傾斜角度 $14^{\circ}$ ) に各一台設置されている。分光放射計は同社製の可視光領域日射計 (MS-700:350 1050nm) と赤外線領域日射計 (MS-712:900～1700nm) が傾斜面（南向き，傾斜角度 $14^{\circ}$ ）を各 1 台設置している。全ての計 測データの計測間隔は 1 分である。

\section{2 本研究のテーマ}

\section{（1）日射量の分離モデルと合成モデルの最適組み合わせ検討}

既往の分離モデルは, 全天日射量を直達成分か天空成分のいずれか を計測し，もう一方を計算によりもとめる。傾斜面日射量は，直達成 分と天空成分を明らかにした上で, 天空放射輝度の空間分布を等方性 か異方性に仮定して合成される。等方性を仮定するモデルは 1 種類の みであるが，異方性を仮定するモデルには様々ある。本研究では，全 天日射量の直達成分も天空成分のいずれも計測していないので, 曽我 他 ${ }^{2)}$ の研究にならい，低緯度帯において既往の分離モデルと合成モデ ルで求めた複数パターンについて, 傾斜面日射量の予測值と実測值の 精度を比較し，予測誤差を最小にする組み合わせは何かを検討する。

（2）分光放射照度推定モデルの作成

分光放射照度の推定には, Bird モデル ${ }^{6}$ が一般的に用いられるが, Rayleight 散乱，エアロゾル，オゾン，水蒸気やその他気体成分の透 過率を入手する必要がある。しかし時系列に変化するその值を入手 することは困難であり，代わりに全天日射強度との強い相関性を利 用し，その他の気象情報（直達日射強度，雲量，可降水量など）も 考慮することで，分光放射照度を推定する方法が検討されている 3), 4),5)。本研究でも同様に入手可能な気象情報を用いて分光放射照度 推定精度の高いモデルの作成方法について検討する。

\section{3 用語・記号の定義}

日射強度：瞬間日射量 $\left[\mathrm{W} \cdot \mathrm{m}^{-2}\right]$

日射量 : 単位時間 $\mathrm{u}$ における日射強度積分值 $\left[\mathrm{Wh} \cdot \mathrm{m}^{-2} \cdot \mathrm{u}^{-1}\right]$

降雨日：日降雨量 0.01 inch以上の日（バンコク気象台による） 非降雨日：日降雨量0.01inch以下の日（バンコク気象台による) $\operatorname{AVE}(\lambda)$ : 観測分光波長 $\lambda$ の放射照度の平均值

RMSE : Root Mean Square Error : 平均2乗平方根誤差

$$
\begin{aligned}
& R M S E=\sqrt{\frac{\sum\left(E_{i}-A_{i}\right)^{2}}{N}} \\
& \text { ただし } E \text { : 推定值, } A \text { : 真值 }
\end{aligned}
$$

$J_{0}$ : 太陽定数 $\left(\mathrm{Z}\right.$ モデル $1,382 \mathrm{~W} \cdot \mathrm{m}^{-2}$, 他のモデル $\left.1,367 \mathrm{~W} \cdot \mathrm{m}^{-2}\right)$ $h, \beta$ : 太陽高度, 水平面に対する傾斜面角度 $\left.{ }^{\circ}\right]$

$I_{G}, I_{n}, I_{d}, I_{T, G}, I_{T, b}, I_{T, d}, I_{T, r}$ : 水平面全天日射量,法線面直達日 射量, 水平面天空日射量, 傾斜面全天日射量,傾斜面直達日射 量，傾斜面天空日射量，地表面反射日射量 $\left[\mathrm{Wh} \cdot \mathrm{m}^{-2} \cdot \mathrm{h}^{-1}\right]$

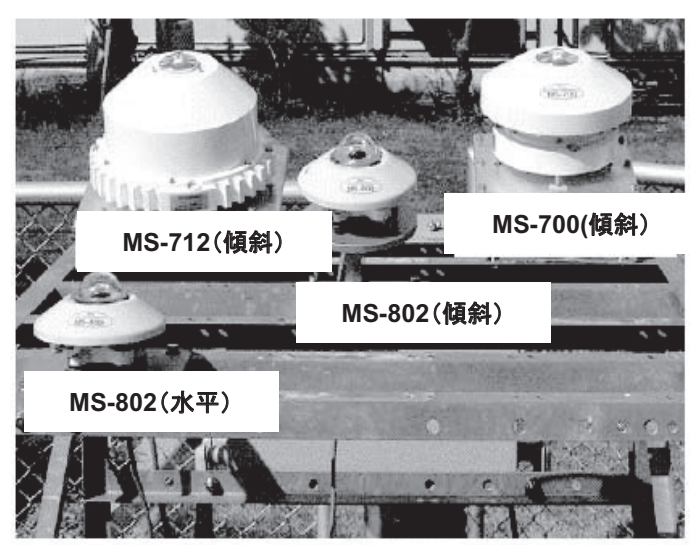

図 1 全天日射計・分光放射計の設置状況

表 1 日射計の仕様

\begin{tabular}{|c|c|c|c|c|c|}
\hline \multirow{2}{*}{ 種類 } & \multirow{2}{*}{ 型式 } & \multirow{2}{*}{ 波長 $[\mathrm{nm}]$} & \multicolumn{2}{|c|}{ 設置面 } & \multirow{2}{*}{ 製造 } \\
\cline { 4 - 6 } & & & 水平 & 傾斜* & \\
\hline \multirow{2}{*}{ 分光放射計 } & MS-700 & $350 \sim 1050$ & - & $\bigcirc$ & \multirow{2}{*}{ 英弘 } \\
\cline { 2 - 5 } & $\mathrm{MS}-712$ & $900 \sim 1700$ & - & $\bigcirc$ & 精機 \\
\hline 全天日射計 & MS-802 & $305 \sim 2800$ & $\bigcirc$ & $\bigcirc$ & \\
\hline
\end{tabular}

*: 傾斜面：南向き $14^{\circ}$
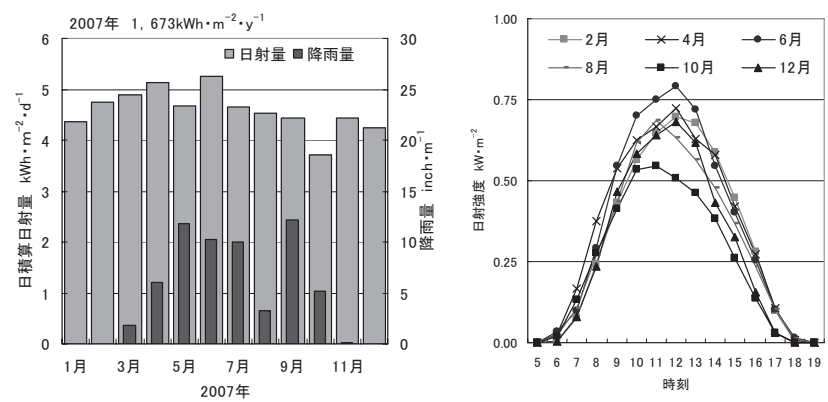

図2 各月の日積算日射量平均と日平均日射量カーブ

$\begin{array}{lll}F & : \text { 形態係数 } & {[-]} \\ \beta & : \text { 水平面に対する傾斜面角度 } & {\left[{ }^{\circ}\right]} \\ \rho: \text { アルベド, } 0.2 \text { と仮定 } & {[-]} \\ \lambda: \text { 波長 } & {[\mathrm{nm}]} \\ W: \text { 可降水量 } & {\left[\mathrm{cm}=g / \mathrm{cm}^{2}\right]} \\ T_{d p}: \text { 露天温度 } & {\left[{ }^{\circ} \mathrm{C}\right]} \\ x: \text { 正規化可降水量 } & {[-]} \\ I & : \text { 全天日射強度 } & {\left[\mathrm{kW} \cdot \mathrm{m}^{-2}\right]}\end{array}$

$\mathrm{I}_{\lambda}, \mathrm{y}_{\lambda}$ : 波長 $\lambda$ の分光放射照度推定値, 波長 $\lambda$ の分光放射照度 $\left[\mathrm{W} \cdot \mathrm{m}^{-2} \cdot \mu \mathrm{m}^{-1}\right]$

$a_{\lambda}, b_{\lambda}, c_{\lambda}$ : 分光放射照度推定モデルの波長別係数

$x \quad$ : 可降水量 $W$ を正規化した值で，0１を取る

\section{3.バンコクの年間日射量及び日射強度計測結果}

\section{1 月別全天日射量}

図 2 に 2007 年の月別水平面全天日射量の計測結果と, 降雨量及び 時刻別全天日射強度カーブを示す。年間の水平面全天日射量は $1,673 \mathrm{kWh} \cdot \mathrm{m}^{-2} \cdot \mathrm{y}^{-1}\left(4.6 \mathrm{kWh} \cdot \mathrm{m}^{-2} \cdot \mathrm{d}^{-1}\right)$ である。日射量最大月は 6 
月の $5.3 \mathrm{kWh} \cdot \mathrm{m}^{-2} \cdot \mathrm{d}^{-1}$ である。最低は 10 月の $3.7 \mathrm{kWh} \cdot \mathrm{m}^{-2} \cdot \mathrm{d}^{-1}$ であ るが，ともにタイ国では雨期に相当する。乾期の 12 月〜 2 月の 3 ケ月 間の平均日射量は $4.5 \mathrm{kWh} \cdot \mathrm{m}^{-2} \cdot \mathrm{d}^{-1}$ である。

\section{2 分光放射照度}

図3にJISの基準太陽光 ${ }^{7)}$ （エアマス 1.5 , 日射強度 : $1 \mathrm{~kW} \cdot \mathrm{m}^{-2}$, 可 降水量 $1.42 \mathrm{~cm}$, 大気オゾン含有量 $0.34 \mathrm{~cm}$, 混濁係数 0.27 , アルベド 0.2 , 測定面傾斜角度 $37^{\circ}$ ） と, 各月の分光放射照度カーブの日照 可能時間平均 (以下”可日照時間”) と, 南中時刻前後 30 分平均 (以下 “南中時” ) を示す。基準太陽光カーブ中, 放射照度最大は $\lambda=420$ $\mathrm{nm}$ で放射照度は $1,184 \mathrm{~W} \cdot \mathrm{m}^{-2} \cdot \mu \mathrm{m}^{-1}$ である。6月の南中時同波長放射 照度は基準光の $84 \%$ 相当である。年間を通じて同波長放射照度が最も 小さいのは, 10 月で基準光の $50 \%$ 相当である。可日照時間帯中の平均 值で比較すると, 最大は1月で同波長放射照度は基準光の約 $45 \%$ 相当 である。最低は10月の $35 \%$ 相当である。

\section{3 全天日射強度と分光放射照度の相関性}

図 4 に全天日射強度と波長別分光放射照度の相関性の一例を示寸。 両者の相関性は高く, 特に $\lambda=900 \mathrm{~nm}$ 以下の全天日射強度は, 決定係 数 $r^{2}=0.8 \sim 0.9$ と高い值を示す。しかし $\lambda=930 \mathrm{~nm}$ 以上では $r^{2}=0.42$ $\sim 0.8$ と不安定で, $937 \mathrm{~nm}$ や $1350 \mathrm{~nm}$ では $r^{2}=0.52 ， 0.42$ と極小值を 示寸。これは空気中の水蒸気吸収帯の影響と考えられる。

\section{4. 検討結果}

\section{1 最適分離・合成モデル}

\section{(1) 最適モデル組み合わせの探索}

本研究では全天日射の各種成分（直達, 天空, 反射）計測を行って いないため, 水平面全天日射量を, 既往の分離モデルで分離した後, やはり既往の合成モデルで傾斜面值に合成し，実測值との比較で RMSE を求める。これを複数モデルの組み合わせで実施し RMSE が最 小となる組み合わせをもって最適組み合わせと考える。

分離モデルは（1）式，合成モデルは（2）式の各要素を求めるも ので, 今回検討したのは, 既往の分離モデル 6 種類と合成モデル 4 種 類で表 2 と表 3 に示す。組み合わせは 24 通りで, 地表面反射率 $\rho$ は 全て 0.2 と仮定した

$$
\begin{aligned}
& I_{G}=I_{n}+I_{d c} \\
& I_{T, G}=I_{T, b}+I_{T, d}+I_{T, r}
\end{aligned}
$$

なお精度評価に用いるデータは, 2007 年計測值で, その内でも太陽高 度 $20^{\circ}$ 以上の場合である。これは, 太陽光の低角入射時の屈折や反射, 敷地内の建物, 樹木, 交通（主に歩行者）による日陰発生の影響を排 除するためである。可日照時間中, 太陽高度が $20^{\circ}$ 未満となる時間は 全可日照時間の $13 \%$ であり,モデル評価への影響は小さいと考えられ る。

\section{（2）モデル組み合わせ別予測精度の検討}

分離・合成モデルの組み合わせ別傾斜面日射量の推測結果と実測值 の関係を図 5 に示す。検討した分離モデル 6 種類全てにおいて, 合成 モデル I’ との組み合わせが RMSE 最小となる。I ‘モデルは 天空の放 射日射の空間分布を等方的と仮定するモデルである。特に W モデル との組み合わせが最小で $\mathrm{RMSE}=0.010$ となる。次いで小さいのは $\mathrm{U}$ と Z モデルであり， RMSE $=0.011$ である。 3 モデルの RMSE の相違 は $10 \%$ とさく, この 3 モデルの精度はほぼ同一と考えられる（最適 組み合わせとなった分離モデルと合成モデルの概要は, 注 1) 参照)。

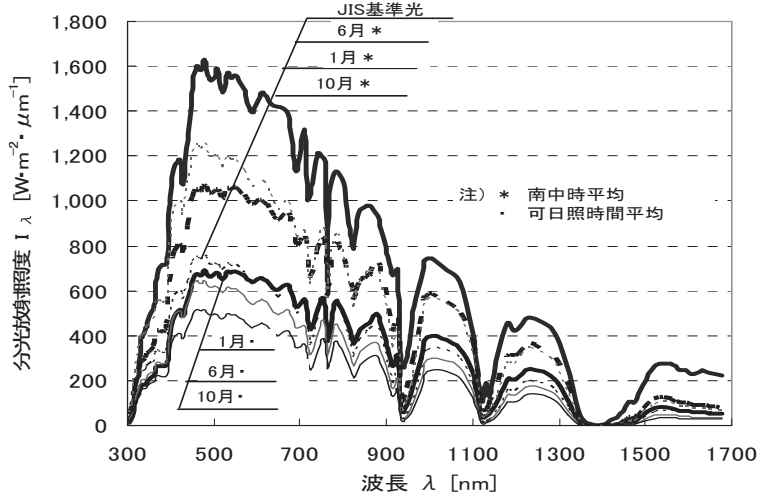

図 3 各月分光放射照度カーブ（日照時間平均と南中時平均）

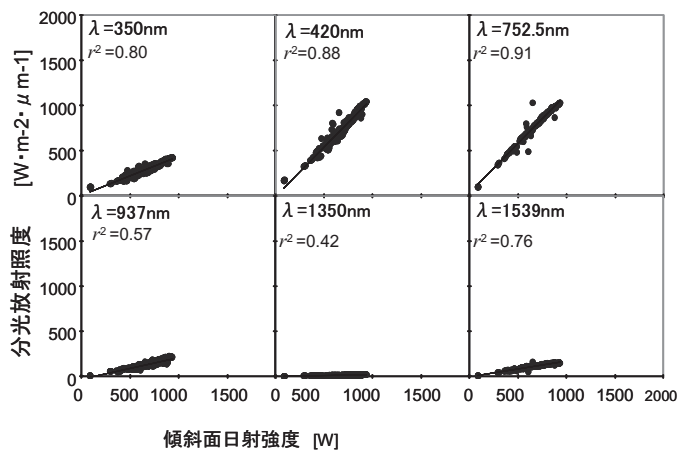

図 4 波長別放射照度と全天日射強度

\begin{tabular}{|c|c|c|}
\hline モデル & 開発者 & (開発時期) \\
\hline $\mathrm{E}$ & Erbs, Klein \& Duffie ${ }^{8)}$ & $(1982)$ \\
\hline M & Maxwell 9) & $(1987)$ \\
\hline $\mathrm{R}$ & Reindl, Beckman \& Duffie ${ }^{10)}$ & $(1990)$ \\
\hline $\mathrm{U}$ & 宇田川 \& 木村 ${ }^{11)}$ & $(1978)$ \\
\hline W & 渡辺, 浦野\& 林 ${ }^{12)}$ & $(1983)$ \\
\hline Z & 張 13) & ( 2004 ) \\
\hline
\end{tabular}

表 2 分離モデルの表記方法及び開発者

\begin{tabular}{|c|c|c|}
\hline モデル & 開発者 & (開発時期) \\
\hline I' & 天空放射輝度空間分布一様仮定 & - \\
\hline $\mathrm{H}^{\prime}$ & Hay ${ }^{14)}$ & $(1979$ ) \\
\hline $\mathrm{S}^{\prime}$ & Skartveit \& Olseth ${ }^{15)}$ & ( 1987 ) \\
\hline $\mathrm{R}^{\prime}$ & Reindl, Beckman \& Duffie ${ }^{10)}$ & $(1990)$ \\
\hline
\end{tabular}

表 3 合成モデルの表記方法及び開発者

なお「天空放射輝度空間分布が等方的」と仮定するモデルの RMSE が最小となった事は，14ㄷいう低傾斜角度であることを考慮すると 天空放射が “等方的”とまでは断定できず，低緯度帯においては，同 分布を “等方的” と仮定しても, 最適傾斜角度の傾斜面日射量推定の 誤差が小さく実用的であることを示すものと考えられる。

\section{2 分光放射照度推定モデルの作成}

\section{(1) モデル作成用データの前処理}

放射照度は全天日射強度と強い相関性があるが，波長別の比例係数 は異なっているので波長毎に放射照度推定モデルを作成する。なお 
用いるデータは全て瞬時值となるが，計測している全ての気象デー 夕及び太陽電池関連データは切り替え装置により逐次処理されてお り，測定タイミングにわずかなズレ(最大 1 秒以内) が発生する。計測 器毎の反応速度も異なるので, 計測時刻のわずかなズレの影響を回避 するため，分析には 5 分間データの移動平均值を用いる。

\section{（2）説明変数の検討}

分光放射照度推定モデルの説明変数として, 最初に全天日射強度 や水蒸気の影響を検討する。

分光日射照度と全天日射強度との相関性の指標として決定係数 $r^{2}$ を, 水蒸気帯の影響の指標として Koepke ${ }^{15}$ らによる波長別水蒸気吸 収因子強度を図 6 に示寸。決定係数 $r^{2}$ は, 全ての日のデータ, 降雨 日データ, 非降雨日データ別分析值である。非降雨日の全天日射強 度との相関性は悪く, 水蒸気による 2 つ吸収帯 $(\sigma, \phi)$ 付近の $r^{2}$ は 0.5 前後と小さい。 3 つめの吸収帯 $\phi$ では, 吸収帯の両端部分が 0.4 以下まで低下寸るが, 中心部分の $\lambda_{1395 \mathrm{~mm}}$ の $r^{2}$ は 0.8 以上と大き な値を示す。これは地表への日射到達量が小さい（基準光で $\left.\lambda_{1395 \mathrm{~mm}}=2 \mathrm{~W} \cdot \mathrm{m}^{-2} \cdot \mu \mathrm{m}^{-1}\right)$ ことが原因と考えられる。

しかし降雨日の $r^{2}$ は安定していて, 全ての波長で 0.8 以上を示す。 これは降雨日の水蒸気分圧が終日高く, 影響がほぼ一定である事が 原因と考えられる。

\section{（3）可降水量の推定}

水蒸気の影響は, 大気中の可降水量 $W$ を映したものと考えるこ とができるので, 可降水量Wの推定值をもとめ, 放射照度の説明変 数とする ${ }^{3)}$ 。可降水量 $W$ を地上気象データから推定するにはWright ら ${ }^{18)}$ の近似式があり, 式（3）に示す。

$$
W=\exp \left(0.0693 \cdot T_{d p}-0.0756\right)
$$

非降雨日は, 分光放射照度と全天日射強度との相関性が水蒸気吸 収帯で悪化することから，可降水量 $W$ こる影響が変化することが 予想される。一方降雨日は, 水蒸気吸収帯でも全天日射強度との相 関性が高いことから, 水蒸気による吸収の影響量があまり変化して いないことが予想される。分光放射照度への可降水量の影響量は非 線形になっていると考えられる。非線形の関係をモデルに考慮する 方法としては，シグモイド関数 ${ }^{(6)}$ などがある。

\section{（4）分光放射照度推定モデルの作成}

分光放射照度の推定モデルとして, 全天日射強度, 降雨の有無, エアマス, 可降水量を変数としてモデルを作成する。これらの関係 をまとめ分光放射照度モデルを波長別に（4），（5）でもとめる。

$$
\begin{aligned}
& y_{\lambda}=a_{\lambda}+b_{\lambda} I+c_{\lambda} s(x) \\
& s(x)=1 /\left(1-e^{x}\right)
\end{aligned}
$$

シグモイド関数 $s(x)$ は, 可降水量 $W=4 \mathrm{~cm}$ でほぼ収束状態になること を考慮したもので, 可降水量 $W$ は，0から1の值で正規化され

$$
\begin{aligned}
& 4 \mathrm{~cm} \geqq W \geqq 1 \mathrm{~cm} \text { のとき } x=(W-1) /(4-1)=(W-1) / 3 \\
& W<1 \mathrm{~cm} \text { のとき } x=0
\end{aligned}
$$

として $x$ が得られる。なおモデルはエアマスの值（ニュートン法で RMSE 最小条件として求めた境界条件 1.5）も考慮すると, シグモイ ド関数導入により全ての水蒸気吸収帯で RMSE の向上が表 4 で確認 される。このモデルの係数 $a_{\lambda}, b_{\lambda}, c_{\lambda}$ を一般的な重回帰分析の手法に よりもとめた結果を表 5 に示す。提案モデルは, エアマス区分 $(2$ 区分），降雨日，非降雨日別にもとめた 4 グループ回帰式の波長別

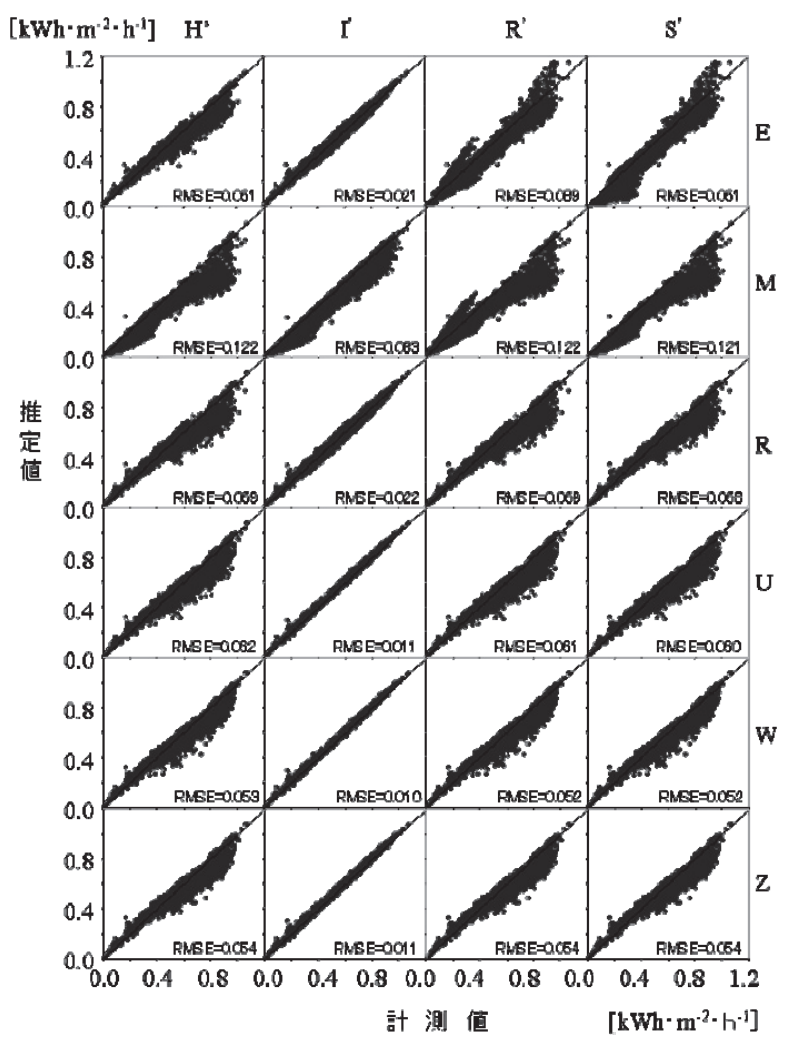

図5＼cjkstart傾斜面全天日射量実測值と推定值の相関性

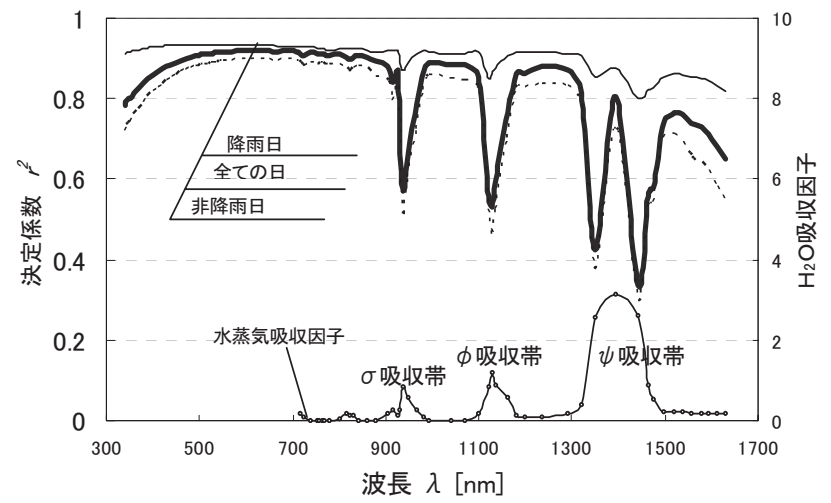

図 6 波長別全天日射量との相関性と水蒸気吸収因子. ${ }^{15)}$

表4 シグモイド関数導入効果（水蒸気吸収帯部RMSE改善状況）

\begin{tabular}{|c|c|c|c|c|}
\hline \multirow{2}{*}{ モデル } & \multicolumn{4}{|c|}{$\operatorname{RMSE}_{\lambda}$} \\
\cline { 2 - 5 } & $\sigma$ 帯 & $\phi$ 帯 & \multicolumn{2}{|c|}{$\phi$ 帯波長nm } \\
\cline { 2 - 6 } & 937 & 1130 & 1350 & 1442.5 \\
\hline 単回帰モデル & 28.1 & 18.5 & 3.09 & 3.54 \\
\hline 非シグモイド関数モデル & 15.4 & 10.2 & 1.83 & 1.94 \\
\hline シグモイド関数モデル & 14.7 & 9.7 & 1.77 & 1.83 \\
\hline
\end{tabular}

決定係数を図 7 に示寸。非降雨日の水蒸気吸収帯 $\phi$ の両端部 $r^{2}$ も 0.3 から 0.6 まで向上する。 $\operatorname{RMSE}(\lambda) / \operatorname{AVE}(\lambda)$ も， $\lambda=1300 \mathrm{~nm}$ 以上の 長波長域での精度向上が顕著である。

5. まとめ

筆者らは，2005年 12 月よりバンコク郊外(北緯 $14^{\circ}$ 東経 $100.5^{\circ}$ ) 
表5 分光放射照度推定モデルの係数と決定係数

\begin{tabular}{|c|c|c|c|c|c|c|c|c|c|c|c|c|c|c|c|}
\hline & & & 非降雨 & (降 & 量 $<0.01$ & עf) & & & & & 降雨日 & (降雨) & $>0.01$ & (f) & \\
\hline 波長[nm] & & $\overline{A M \geqq}$ & & & & & & & & $\overline{A M \geqq}$ & & & & $\overline{A M}$ & \\
\hline & a & $\mathrm{b}$ & $c$ & $\frac{r^{2}}{2}$ & a & $\mathrm{b}$ & $c$ & $r^{2}$ & a & $\mathrm{b}$ & $c$ & $\frac{r^{2}}{2}$ & a & $\mathrm{b}$ & $c$ \\
\hline 340.0 & -57.2 & 309.1 & 124.1 & 0.81 & -157.8 & 346.9 & 303.5 & 0.74 & -332.1 & 362.1 & 501.8 & 0.90 & -260.8 & 436.1 & 412.8 \\
\hline 345.0 & -61.1 & 334.4 & 129.8 & 0.82 & -159.7 & 371.9 & 307.6 & 0.75 & -341.5 & 389.7 & 514.9 & 0.91 & -258.3 & 463.5 & 409.5 \\
\hline 350.0 & -64.1 & 352.1 & 134.4 & 0.82 & -163.4 & 390.2 & 314.5 & 0.76 & -351.1 & 409.1 & 528.8 & 0.91 & -263.4 & 484.4 & 417.1 \\
\hline 360.0 & -68.6 & 385.3 & 139.1 & 0.84 & -164.4 & 422.8 & 315.3 & 0.77 & -357.9 & 443.4 & 537.0 & 0.92 & -260.3 & 518.6 & 411.0 \\
\hline 370.0 & -80.9 & 469.0 & 160.2 & 0.85 & -182.8 & 509.0 & 351.8 & 0.79 & -408.7 & 535.0 & 611.4 & 0.93 & -288.7 & 617.9 & 455.5 \\
\hline 380.0 & -78.4 & 471.2 & 151.2 & 0.87 & -166.7 & 505.7 & 321.7 & 0.80 & -382.2 & 532.5 & 569.7 & 0.94 & -261.2 & 607.4 & 411.5 \\
\hline 390.0 & -79.1 & 498.6 & 149.5 & 0.88 & -156.7 & 527.8 & 306.1 & 0.81 & -378.9 & 558.6 & 563.0 & 0.94 & -253.7 & 627.2 & 399.4 \\
\hline 400.0 & -112.6 & 746.0 & 209.4 & 0.89 & -207.0 & $\overline{778.6}$ & 412.2 & 0.82 & -537.1 & 8297 & 795.3 & 0.95 & -358.7 & 917.1 & 563.7 \\
\hline 410.0 & -133.4 & 923.0 & 245.0 & 0.90 & -228.6 & 951.1 & 465.1 & 0.83 & -634.6 & $1,020.8$ & 937.2 & 0.95 & -424.8 & $1,112.0$ & 667.1 \\
\hline 420.0 & -135.4 & 974.8 & 244.7 & 0.91 & -216.7 & 994.1 & 448.4 & 0.84 & -634.5 & $1,071.0$ & 934.5 & 0.96 & -422.3 & $1,152.9$ & 662.5 \\
\hline 430.0 & -125.1 & 935.8 & 222.5 & 0.91 & -188.1 & 945.8 & 395.0 & 0.85 & -577.6 & $1,021.6$ & 848.5 & 0.96 & -381.9 & $1,088.5$ & 598.6 \\
\hline 440.0 & -139.4 & $1,097.7$ & 244.6 & 0.92 & -197.7 & $1,101.0$ & 422.8 & 0.85 & -637.5 & $1,190.2$ & 934.3 & 0.96 & -421.5 & $1,257.7$ & 659.5 \\
\hline 450.0 & -155.1 & $1,263.7$ & 268.3 & 0.93 & -206.8 & $1,258.2$ & 449.6 & 0.86 & -699.9 & $1,362.7$ & $1,023.3$ & 0.96 & -465.9 & $1,427.7$ & 727.4 \\
\hline 460.0 & -157.5 & $1,319.3$ & 268.9 & 0.93 & -197.6 & $1,304.8$ & 436.3 & 0.86 & -696.2 & $1,415.2$ & $1,015.8$ & 0.96 & -470.3 & $1,470.9$ & 732.8 \\
\hline 470.0 & -150.7 & $\begin{array}{l}1,322.8 \\
\end{array}$ & $\begin{array}{l}253.7 \\
\end{array}$ & $\begin{array}{l}0.94 \\
\end{array}$ & -177.4 & $\frac{1,30.01 .1}{1,301}$ & 400.1 & 0.87 & $\begin{array}{l}-655.4 \\
-5.4\end{array}$ & $\begin{array}{l}, 1,40.4 \\
1,409.7\end{array}$ & $\begin{array}{r}, 054.4 \\
954\end{array}$ & $\begin{array}{l}0.90 \\
\end{array}$ & -446.6 & $\begin{array}{l}, 4,456.7 \\
1,4\end{array}$ & $\begin{array}{l}694.4 \\
\end{array}$ \\
\hline 480.0 & -153.6 & $1,372.4$ & 253.8 & 0.94 & -171.5 & $1,344.5$ & 389.2 & 0.87 & -651.0 & $1,455.1$ & 944.9 & 0.97 & -449.6 & $1,496.4$ & 695.7 \\
\hline 490.0 & -138.7 & $1,324.7$ & 228.5 & 0.95 & -141.3 & $1,288.1$ & 337.2 & 0.87 & -593.8 & $1,397.1$ & 861.5 & 0.97 & -416.3 & $1,424.5$ & 645.5 \\
\hline 500.0 & -130.4 & $1,353.2$ & 212.7 & 0.95 & -121.2 & $1,310.1$ & 305.5 & 0.88 & -562.5 & $1,416.6$ & 815.4 & 0.97 & -399.6 & $1,439.4$ & 619.8 \\
\hline 510.0 & -119.9 & $1,365.0$ & 193.3 & 0.96 & -100.0 & $1,316.9$ & 270.3 & 0.88 & -528.8 & $1,418.7$ & 765.6 & 0.97 & -376.6 & $1,437.9$ & 584.4 \\
\hline 520.0 & $\begin{array}{l}-124.7 \\
\end{array}$ & $1,317.3$ & 200.8 & $\begin{array}{ll}0.96 \\
\end{array}$ & -102.5 & $1,263.8$ & 270.3 & $\begin{array}{l}0.88 \\
\end{array}$ & -515.1 & $1,370.7$ & 745.3 & 0.97 & -400.6 & $1,375.3$ & 618.8 \\
\hline 530.0 & -127.9 & $1,384.6$ & 203.7 & 0.96 & -99.6 & $1,325.0$ & 269.0 & 0.88 & -521.7 & $1,433.9$ & 754.1 & 0.97 & -422.6 & $1,434.9$ & 651.4 \\
\hline 540.0 & -116.5 & $1,387.2$ & 184.6 & 0.96 & -79.2 & $1,323.0$ & 236.6 & 0.88 & -484.4 & $1,427.5$ & 700.4 & 0.97 & -404.2 & $1,424.8$ & 623.9 \\
\hline 550.0 & -115.1 & $1,403.0$ & 181.0 & 0.97 & -72.3 & $1,333.8$ & 225.1 & 0.89 & -471.4 & $1,439.1$ & 680.8 & 0.97 & -411.1 & $1,430.6$ & 633.0 \\
\hline 570.0 & -98.3 & $1,368.0$ & $\begin{array}{l}146.7 \\
\end{array}$ & 0.97 & -48.1 & $1,301.8$ & 172.9 & 0.89 & -390.9 & $1,384.2$ & 561.3 & 0.97 & -352.9 & $1,382.2$ & 538.8 \\
\hline 590.0 & -9.9 & $1,323.9$ & 4.2 & 0.97 & 82.0 & $1,257.5$ & -35.4 & 0.89 & -210.5 & $1,294.8$ & 304.3 & 0.97 & -147.2 & $1,308.8$ & 235.3 \\
\hline 610.0 & -90.9 & $1,356.8$ & 134.8 & 0.97 & -24.8 & $1,278.3$ & 128.7 & 0.89 & -334.2 & $1,364.0$ & 477.7 & 0.97 & -352.6 & $1,337.3$ & 535.1 \\
\hline 630.0 & -74.6 & $1,298.4$ & 105.5 & 0.98 & -7.6 & $1,226.1$ & 87.3 & 0.89 & -259.1 & $1,295.2$ & 367.3 & 0.97 & -289.6 & $1,273.2$ & 434.2 \\
\hline 600.0 & 1.7 & $\frac{1,255.9}{1,255}$ & -12.0 & $\begin{array}{l}0.98 \\
\end{array}$ & $\begin{array}{r}104.0 \\
\end{array}$ & $\frac{1,2<1}{1,177.1}$ & -85.0 & 0 & $\begin{array}{l}20.1 \\
-120.5\end{array}$ & $\begin{array}{l}1,221.4 \\
\end{array}$ & $\begin{array}{l}172.2 \\
\end{array}$ & \begin{tabular}{|l|}
0.97 \\
\end{tabular} & $\begin{array}{r}200.0 \\
-133.3\end{array}$ & $\begin{array}{l}, 2,202.4 \\
1,24\end{array}$ & $\begin{array}{l}408.2 \\
208.0\end{array}$ \\
\hline 670.0 & -53.2 & $1,304.4$ & 79.5 & 0.98 & 41.5 & $1,209.1$ & 15.9 & 0.89 & -197.4 & $1,297.7$ & 280.4 & 0.97 & -280.2 & $1,239.7$ & 423.9 \\
\hline 690.0 & -20.4 & $1,108.8$ & 19.5 & 0.98 & 54.3 & $1,047.6$ & -34.2 & 0.89 & -93.8 & $1,081.7$ & 129.5 & 0.97 & -150.8 & $1,063.2$ & 221.1 \\
\hline 710.0 & 45.3 & $\frac{1,160.0}{1,160 .}$ & -71.0 & $\begin{array}{l}0.98 \\
\end{array}$ & $\begin{array}{l}156.6 \\
\end{array}$ & $1,081.6$ & -16.6 .7 & 0.89 & 0.3 & $1,118.8$ & 5.8 & 0.97 & -98.7 & $\frac{1,085.1}{1,08}$ & 160.9 \\
\hline 718.0 & 145.0 & $1,008.1$ & -229.4 & 0.98 & 296.7 & 942.5 & -387.4 & 0.89 & 136.4 & 920.0 & -184.4 & 0.97 & 102.0 & 924.7 & -132.0 \\
\hline 724.4 & 221.0 & 893.8 & -351.3 & 0.97 & 400.2 & 843.1 & -552.4 & 0.89 & 245.1 & 773.1 & -336.9 & 0.97 & 265.5 & 808.3 & -371.2 \\
\hline 740.0 & 94.9 & $1,058.5$ & -141.4 & 0.98 & 212.5 & 983.6 & -248.2 & 0.89 & 65.9 & 996.4 & -78.5 & 0.97 & -65.4 & 972.8 & 120.8 \\
\hline 752.5 & -39.7 & $1,150.9$ & 84.4 & 0.98 & 29.4 & $1,055.0$ & 50.9 & 0.88 & -147.1 & $1,151.0$ & 230.9 & 0.97 & -423.6 & $1,063.7$ & 658.2 \\
\hline 757.5 & -47.7 & $1,029.9$ & 90.4 & 0.98 & -2.8 & 959.3 & 79.3 & 0.88 & -136.4 & $1,028.9$ & 211.6 & 0.97 & -392.2 & 966.5 & 601.0 \\
\hline 762.5 & -50.4 & 767.6 & 80.9 & 0.98 & -40.9 & 738.5 & 99.3 & 0.88 & -103.1 & 763.4 & 154.5 & 0.97 & -282.8 & 744.3 & 420.6 \\
\hline 767.5 & -56.7 & 806.8 & 88.5 & 0.98 & -47.5 & 778.0 & 107.7 & 0.88 & -101.5 & 802.1 & 150.5 & 0.97 & -292.6 & 783.9 & 432.0 \\
\hline 780.0 & -48.0 & $\begin{array}{r}1,114.4 \\
\end{array}$ & 99.4 & 0.97 & 10.5 & $\begin{array}{l}1,022.7 \\
\end{array}$ & 75.0 & 0.87 & $\begin{array}{r}-136.2 \\
\end{array}$ & $1,117.4$ & 216.6 & $\begin{array}{l}0.96 \\
\end{array}$ & -446.8 & $1,026.5$ & $\begin{array}{l}691.6 \\
\end{array}$ \\
\hline 800.0 & 39.7 & $1,016.2$ & -45.1 & 0.98 & 124.1 & 937.3 & -113.2 & 0.88 & 31.6 & 979.5 & -25.7 & 0.97 & -212.7 & 924.3 & 340.6 \\
\hline 816.0 & 154.7 & $\frac{1,06.2}{863.0}$ & $\begin{array}{r}-233.7 \\
-233.7\end{array}$ & $\begin{array}{l}0.97 \\
\end{array}$ & 287.1 & 804.5 & $\frac{11.2}{-376.2}$ & 0 & $\begin{array}{l}197.4 \\
\end{array}$ & 777.5 & -263.9 & 0.97 & $\begin{array}{r}21.7 \\
5.8\end{array}$ & $\begin{array}{l}7724.0 \\
771.2\end{array}$ & $\begin{array}{l}34.06 .9 \\
\end{array}$ \\
\hline 823.7 & 195.1 & 754.7 & -302.4 & 0.97 & 342.0 & 709.2 & -470.8 & 0.88 & 254.6 & 652.0 & -347.7 & 0.96 & 178.3 & 668.0 & -243.2 \\
\hline 831.5 & 150.1 & 816.8 & -228.6 & \begin{tabular}{|l|l}
0.97 \\
\end{tabular} & 271.4 & 764.0 & -361.1 & $\begin{array}{ll}0.88 \\
\end{array}$ & 210.6 & $\begin{array}{l}733.3 \\
\end{array}$ & -284.9 & 0.96 & 77.9 & 730.2 & -96.0 \\
\hline 840.0 & 95.5 & 883.6 & -137.9 & 0.97 & 192.2 & 821.8 & -234.4 & 0.88 & 135.2 & 824.6 & -176.5 & 0.96 & -61.7 & 796.3 & 111.1 \\
\hline 860.0 & -15.0 & 922.4 & 45.5 & 0.97 & 39.5 & 847.5 & 7.2 & 0.87 & -14.7 & 912.5 & 39.9 & 0.96 & -322.0 & 835.7 & 498.8 \\
\hline 880.0 & 141.4 & 936.6 & -186.8 & 0.94 & 284.6 & 853.3 & -333.1 & 0.85 & 24.9 & 875.6 & -7.3 & 0.96 & -425.7 & 836.8 & 639.4 \\
\hline 905.0 & 242.8 & 680.8 & -373.1 & 0.94 & 412.2 & 643.5 & -575.9 & 0.87 & 253.8 & 564.7 & -345.3 & 0.96 & 72.0 & 600.2 & -103.4 \\
\hline 915.0 & 306.0 & 533.7 & -478.4 & 0.91 & 517.8 & 507.7 & -742.1 & 0.86 & 315.3 & 391.7 & -434.3 & 0.96 & 281.0 & 450.8 & -404.5 \\
\hline 925.0 & 248.8 & 633.4 & -387.5 & 0.94 & 410.8 & 605.6 & -582.1 & 0.86 & 337.2 & 501.7 & -463.1 & 0.96 & 269.1 & 546.5 & -381.1 \\
\hline 930.0 & 224.5 & 329.4 & -359.4 & 0.80 & 387.8 & 330.0 & -566.1 & 0.72 & 336.5 & 198.5 & -463.7 & 0.88 & 550.3 & 249.9 & -771.8 \\
\hline 937.0 & 177.9 & 125.1 & -281.1 & 0.75 & 344.9 & 125.5 & -502.2 & 0.79 & 134.3 & 51.0 & -184.5 & 0.91 & 241.9 & 86.4 & -343.3 \\
\hline 948.0 & 236.8 & 198.0 & -374.2 & 0.80 & 429.0 & $\begin{array}{l}197.3 \\
\end{array}$ & -627.1 & 0.82 & 196.1 & 97.0 & -270.4 & 0.93 & 294.1 & 149.8 & -421.8 \\
\hline 965.0 & 302.8 & 373.0 & -474.5 & 0.87 & 518.2 & 357.6 & -752.1 & 0.85 & 252.7 & 249.3 & -350.1 & 0.95 & 233.8 & 312.3 & -345.7 \\
\hline $\begin{array}{l}980.0 \\
980.0\end{array}$ & $\begin{array}{l}252.00 \\
258.0\end{array}$ & 585.7 & $\begin{array}{r}-398.3 \\
-398.3\end{array}$ & $\begin{array}{l}.0 .93 \\
\end{array}$ & 429.1 & 552.5 & $\frac{12.11}{-611.0}$ & 0 & $\begin{array}{l}254.8 \\
254.8\end{array}$ & 475.1 & $\begin{array}{r}352.8 \\
\end{array}$ & 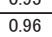 & $\begin{array}{l}78.0 \\
78.2\end{array}$ & 513.9 & $\frac{34.1}{-124.0}$ \\
\hline 993.5 & 84.9 & 779.7 & -116.8 & 0.95 & 164.4 & 732.4 & -202.7 & 0.85 & 170.3 & 728.1 & -228.7 & 0.96 & -176.3 & 706.0 & 256.8 \\
\hline $1,040.0$ & 24.3 & 747.1 & -16.8 & 0.94 & 77.8 & 698.5 & -68.4 & 0.84 & 136.9 & 722. & -178.9 & 0.95 & -266.3 & 677.0 & 395.4 \\
\hline $1,070.0$ & 25.2 & 674.3 & -23.3 & 0.94 & 69.5 & 636.3 & -66.5 & 0.84 & 150.1 & 641.3 & -198.7 & 0.95 & -182.2 & 608.1 & 274.0 \\
\hline $1,100.0$ & 178.4 & 476.7 & -274.3 & 0.93 & 296.6 & 453.7 & -421.4 & 0.84 & 276.2 & 383.7 & -381.2 & 0.95 & 170.6 & 405.4 & -243.0 \\
\hline $1,120.0$ & 113.4 & 85.4 & -179.6 & 0.73 & 216.9 & 88.6 & -317.3 & 0.72 & 104.1 & 34.4 & -143.2 & 0.83 & 197.3 & 56.1 & -277.8 \\
\hline $1,130.0$ & 121.0 & 75.9 & -190.0 & 0.74 & 240 & 75.1 & -349.4 & 0.78 & 74.8 & 30.9 & -102.9 & 0.91 & 122.5 & 53.2 & -175.6 \\
\hline $1,137.0$ & 145.8 & 102.6 & -229.1 & 0.77 & 272.4 & 101.6 & -397.1 & 0.80 & 103.9 & 46.1 & -143.3 & 0.92 & 153.5 & 75.6 & -221.2 \\
\hline $1,161.0$ & 222.9 & 246.4 & -349.0 & 0.87 & 372.5 & 240.3 & -545.0 & 0.84 & 193.1 & 158.9 & -269.0 & 0.94 & 182.8 & 205.5 & -271.9 \\
\hline $1,180.0$ & 136.3 & 421.7 & -212.4 & 0.93 & 224.3 & 407.8 & -327.5 & 0.84 & 244.1 & 351.2 & -343.4 & 0.95 & 137.1 & 370.3 & -206.9 \\
\hline $1,200.0$ & 117.8 & 42 & -184.8 & 0.93 & 190.6 & 408.8 & -280.3 & 0.84 & 252.6 & 356.0 & -357.2 & 0.95 & 144.5 & 370.8 & -218.5 \\
\hline $1,235.0$ & 34.1 & 503.4 & -47.3 & 0.93 & 63.8 & 481.3 & $\frac{20.06}{-86.4}$ & 0.83 & 207.8 & 481.1 & -297.3 & 0.95 & -48.5 & 461.4 & 55.1 \\
\hline $1,290.0$ & 67.7 & 408.8 & -100.4 & 0.92 & 100.4 & 395.4 & -145.5 & 0.83 & 201.9 & 376.4 & -287.7 & 0.95 & 18.3 & 369.5 & -38.4 \\
\hline $1,320.0$ & 122.0 & 230.2 & -192. & 0.91 & 183 & 232 & -276 & 0.82 & 190.0 & 170.6 & -268.0 & 0.94 & 197.9 & 194.4 & -289.8 \\
\hline $1,350.0$ & 12.9 & 9.7 & -20.4 & 0.65 & 31.6 & 10.7 & -45.9 & 0.59 & 7.2 & 4.7 & -9.8 & 0.88 & 20.3 & 6.1 & $\begin{array}{l}28.2 \\
-28.2\end{array}$ \\
\hline $1,395.0$ & 0.8 & 3.1 & -1.3 & 0.76 & 2.0 & 2.8 & -2.7 & 0.74 & -0.3 & 2.7 & 0.4 & 0.89 & -0.4 & 2.8 & 0.5 \\
\hline $1,442.5$ & 18.8 & 9.0 & -29.6 & 0.62 & 46.5 & 9.6 & -67.5 & 0.70 & 6.0 & 2.7 & -8.3 & 0.87 & 20.5 & 5.1 & -29.0 \\
\hline $1,462.5$ & 55.5 & 41.0 & -89.0 & 0.78 & 97.2 & 47.5 & -147.8 & 0.72 & 42.2 & 16.8 & -59.5 & 0.89 & 93.5 & 29.0 & -134.5 \\
\hline $1,477.0$ & 44.6 & 34.3 & -71.7 & 0.79 & 80.0 & 39.2 & -121.4 & 0.73 & 34.6 & 15.0 & -49.0 & 0.90 & 74.4 & 24.7 & -107.3 \\
\hline $1,497.0$ & 71.5 & 105.3 & -118.4 & 0.88 & 92.0 & 119.8 & -154.5 & 0.75 & 105.0 & 69.5 & -152.2 & 0.91 & 155.6 & 90.2 & -232.3 \\
\hline $1,520.0$ & 42.1 & 164.7 & -75.5 & 0.90 & 14.1 & 189.3 & -55.3 & 0.71 & 146.0 & 136.4 & -216.3 & 0.91 & 183.0 & 151.4 & -279.7 \\
\hline $1,539.0$ & 25.5 & 174.6 & -48.6 & 0.89 & -25.3 & 202.9 & -0.5 & 0.68 & 146.6 & 154.1 & -218.3 & 0.91 & 173.3 & 164.5 & -266.4 \\
\hline $1,558.0$ & 13.9 & 165.6 & -28.7 & 0.89 & -51.4 & 198.2 & 37.3 & 0.65 & 139.5 & 151.4 & -207.3 & 0.92 & 166.0 & 158.6 & -253.4 \\
\hline $1,578.0$ & 15.1 & 134.3 & -28.6 & 0.89 & -44.4 & 166.2 & 32.2 & 0.63 & 105.8 & 122.8 & -157.3 & 0.92 & 132.5 & 132.0 & -202.5 \\
\hline $1,592.0$ & 17.4 & 133.3 & -30.5 & 0.89 & -46.1 & 166.2 & 34.8 & 0.61 & 106.6 & 123.2 & -157.8 & 0.93 & 135.6 & 130.4 & -205.4 \\
\hline $1,610.0$ & 10.7 & 118. & -19.9 & 0.89 & -60.5 & 154.8 & 55.6 & 0.58 & 91 & 109.8 & -135.1 & 0.93 & 132.1 & 118.5 & -198.3 \\
\hline $1,630.0$ & 11.1 & 117.1 & -19.6 & 0.89 & -67.2 & 156.4 & 64.1 & 0.54 & 95.1 & 109.2 & -139.8 & 0.93 & 142.1 & 116.7 & -211.1 \\
\hline
\end{tabular}

で全天日射強度, 分光放射照度, 外気温, 相対湿度, 風速・風向, 太陽電池特性の計測を行っており，本研究では，そのデータを用い
て，バンコクの全天日射量の分離モデルと合成モデル，分光放射照

度の推定モデルについて検討した。 
分離モデルと合成モデルの検討にあたっては分離モデル 6 種類と 合成モデル 4 種類の 24 組み合わせを検討し, 推定精度の高いモデル の組み合わせを求めた。この結果分離モデルとしては, $\mathrm{U}^{11)}, \mathrm{W}^{12)}$, $\mathrm{Z}^{13)}$ となった。なお「天空放射輝度空間分布が等方的」と仮定する I “モデルが選択されたことは傾斜角度が $14^{\circ}$ と低角では “等方的” と仮定しても傾斜面日射量推定の誤差が小さく実用的であり，低緯度 帯においては, 最適傾斜角度の推定に “天空放射輝度空間分布を等方 的”とする仮定も有効であることを示しているものと考えられる。

分光放射照度は，全天日射強度との相関性が高いこと，水蒸気に よる吸収の影響を受けること，特に非降雨日に全天日射強度との相 関性の変動幅が大きいことに着目し, 説明変数として全天日射強度, エアマス, 日降雨量の有無, 可降水量（正規化した值でシグモイド 関数処理）を採用し,波長別推定モデルを作成した。作成したモデル では, 水蒸気吸収帯の推定精度向上が確認され, 特に $\lambda=1300 \mathrm{~nm}$ 以上の長波長域での精度向上が顕著であった。

気象情報が十分でない状態で，全天日射量の分離モデルと合成モ デルの最適組み合わせの探索手順や分光放射照度の説明力の高い変 数や非線形性をモデルに導入する手順が明らかになったことで，同 一条件の地域でも，分離モデルと合成モデルの最適組み合わせの探 索や分光放射照度推定モデルの作成が可能になったと考えられる。 この手法の発展により低緯度地域における太陽光エネルギー賦存量 の推定精度の向上や低緯度帯の分光特性研究の進展が期待される。

\section{謝辞}

本研究にあたって，可降水量に関する知見を提供いただいた鹿児 島大学准教授曽我和弘氏，同大学大学院修士課程児島和弘氏に謝意 を表します。また本計測・通信システムは独立行政法人新エネルギ 一・産業技術総合開発機構の平成 17 年度「提案公募型開発支援研究 協力事業」によって設置・運用されているものであり，また本研究 は 2007 年度鹿島学術振興財団研究助成（研究代表者 田中昭雄）に よるものです。ここに記して感謝の意を表します。

参考文献

1）産業創造研究所, 低緯度帯における太陽電池評価の標準化のための研究, NEDO, 2007

2）曽我和弘・赤坂裕・二宮秀輿，全天日射量から斜面日射量を推定する各 種モデルの比較, 日本建築学会計画系論文集, No.519, pp.31 38,1999.5

3）曽我和弘・藤園武史，波長別日射量の推定法に関寸る基礎的研究-その 3 晴天指数とエアマスを考慮した波長別全天日射量の推定法-, 日本建築学 会大会学術講演梗概集 D-2,pp.231 232,2007

4）山際賢一・曽我和弘・藤園武史，波長別日射量の推定法に関する基礎的 研究-その 4 晴天指数・エアマス・可降水量を考慮した波長別全天日射 量の推定法-日本建築学会九州支部研究報告,pp165～68,2008

5）馬場弘志・金山公夫・遠藤登・金澤浩志，太陽エネルギー利用のための 分光日射量の測定と整理（第 1 報,Bird のモデルに基づく分光日射特性の 比較 ），日本機械学会論文集（B 編）,No.599，pp.2847～853，1996.7

6) Bird. R. E. : Solar Energy, Vol. 32. No. 4, pp. 461 471, 1984

7） JIS，JISC 8931 二次基淮アモルファス太陽電池七ル, 1995

8) D.G.Erbs and S.A.Klein,J.A.Duffie, Estimation of the diffuse radiation fraction for hourly, daily and monthly average global radiation, Solar Energy, 28-4, pp.293 302, 1982

9) E.L.Maxwell, A quasi-physical modeling for converting hourly global horizontal to direct normal insolation, Report SERI/TR-215-3087, Solar Energy Research Institute, Golden CO,1986

10) D.T.Reindl, W.A.Beckman and J.A.Duffie, Diffuse fraction correlations, Solar Energy ,No.45,pp. 1 7,1990

11）宇田川光弘・林健一, 水平面全天日射量観測值よりの直達日射量の推定, 日本建 築学会論文報告集, No. 267, pp83～90, 1978. 5

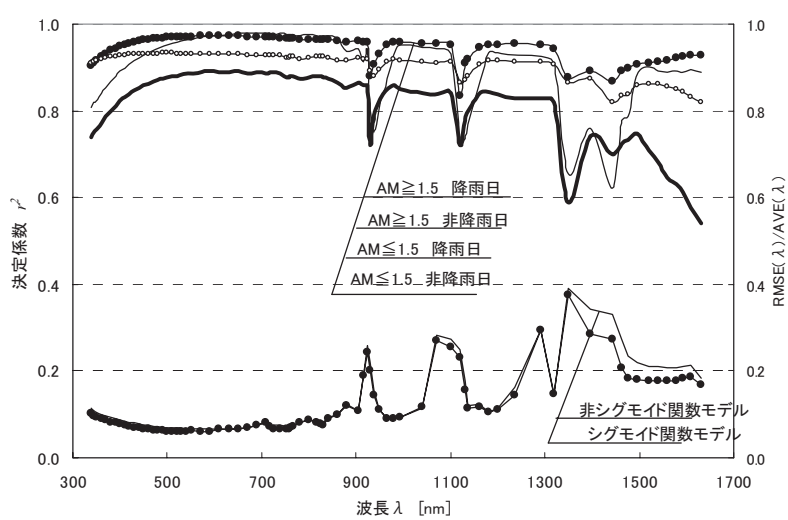

図 7 分光放射照度推定モデルの波長別決定係数 $r^{2}$ と シグモイド関数導入効果

12）渡辺俊行 ・浦野良美・林徹夫，水平面全天日射量の直散分離と傾斜面日射量の推 定，日本建築学会論文報告集，No.330，pp.96～108,1983

13）張 晴原，Compertz 関数による水平面全天日射量の直散分離に関する研究，日本 建築学会環境系論文集, No.580, pp.31 37, 2004. 6

14) Hay,J.E., Study of short-wave Radiation on Non horizontal surfaces, Canadian Climatic Center Report, Atmospheric Environment Service, Toronto Canada , pp.79 12,1979

15) A.Skartveit and J.A.Olseth, Modeling slope irradiance at high latitudes, Solar Energy, 36-4, pp.333 344,1986

16) P.Koepke and H. Quenzel,Water Vapor: Spectral transmission at wavelengths between $0.7 \mu \mathrm{m}$ and $1 \mu \mathrm{m}$, Appl. Optics, No.17, pp. $2114 \sim 2118,1978$

17）伊藤朋恭・金澤洋子・古瀬優美・小寺絵莉・田中さゆり，シミュレーシ ヨン的手法による大気環境情報教育-日射量の天頂角依存性-, 大妻女子 大学紀要-社会情報系-社会情報学研究, No. 14, pp. 101 114, 2005

18） J. Wright et al. : Luminous Efficacy of Direct Irradiance : Variations with Insolation and Moisture Conditions, Solar Energy Vol.42 No.5, pp.387 394, 1989.5

19）上坂吉則 : ニューロコンピューティングの数学的基礎, 近代科学社, 1993

注

注 1） RMSE 最小となる直散分離モデルと合成モデル

（1）直散分離モデル

(1)Uモデル ${ }^{11)}$ (1978)

$K_{T t} \geqq K_{T t c}: I_{n}=\left(-0.43+1.43 K_{T t}\right) / I_{0}$

$K_{T t}<K_{T t c}: I_{n}=\left\{\left(2.277-1.258 \sin h+0.2396 \sin ^{2} h\right) K_{T t}{ }^{3}\right\} / I_{0}$

ただし $K_{T t}=I_{G} /\left(I_{0} \sin h\right)$ $K_{T C}=0.5163+0.333 \sin h+0.00803 \sin ^{2} h$

(2)Wモデル ${ }^{12)}(1983)$

$I_{d}=I_{0} \sin h \cdot\left(K_{T}-K_{D S}\right) /\left(1-K_{D S}\right)$

ただし

$K_{T} \geqq K_{T C}: K_{D S}=K_{T}-\left(1.107+0.03569 \sin h+1.681 \sin ^{2} h\right)\left(1-K_{T}\right)^{3}$

$K_{T}<K_{T C}: K_{D S}=\left(3.996-3.862 \sin h+1.540 \sin ^{2} h\right) K_{T}^{3}$

$K_{T}=I_{G} /\left(I_{0} \sin h\right), K_{T C}=0.4268+0.1934 \sin h$

(3)Z モデル ${ }^{13)}$ (2004)

$I_{n}=K_{n} \cdot J_{0}, I_{d}=I_{G}-I_{n} \sin h$

ただし

$K_{n}=A_{1} A_{2}^{-A_{1} A_{2}^{-1+4 k}}$

$A_{1}=-0.1556 \sin ^{2} h+0.1028 \sin h+1.3748$

$A_{2}=0.7973 \sin ^{2} h+0.1509 \sin h+3.035$

$A_{3}=5.4307 \sin h+7.2182, \quad A_{4}=2.990, \quad K_{T}=I_{G} / J_{0} \sin h$

(2) 合成モデル

I’モデル（一様分布モデル）

$F=(1+\cos \beta) / 2, \quad I_{T, d}=I_{d} F, \quad I_{T, r}=I_{G} \rho \cdot(1-\cos \beta) / 2$ 